\title{
EFFECT OF BACTERIZATION AND FERTILIZERS ON MELONFIELDS PRODUCTIVITY IN SOUTHERN UKRAINE
}

\author{
V. A. Lymar ${ }^{1}$, V. Ye. Dyshliuk ${ }^{2}$, V. O. Podpriadov ${ }^{1}$, P. A. Marchuk ${ }^{1}$ \\ ${ }^{1}$ Southern State Agricultural Experiment Station, Institute of Water Problems and Land \\ Reclamation, NAAS, Hola Prystan \\ 71, Chervonoarmiiska Str., Hola Prystan Town, Kherson region, 75600, Ukraine \\ e-mail: ipobuaan@gmail.com \\ ${ }^{2}$ National Academy of Agrarian Sciences of Ukraine, Kyiv City \\ Ukraine, 03022, city of Kyiv; 37, Vasylkivska Str., e-mail: dishlyuk@yandex.ru
}

Today, due to the crisis in the environment, violation of ecological balance in agricultural ecosystems through intensification of agriculture because of excessive application of chemicals it is almost impossible to get high yields of crops with high-quality products. In this situation, an alternative to traditional (intensive) farming can be a biological agriculture [1]. One of the main principles of such farming is biogenicity, i.e. strengthening the role of biological factors in growing crops. A powerful factor of optimization of the production process of crops under these conditions is the use of preparations based on living cultures of agronomically valuable microorganisms. These bacteria are the major factor of intensification of soil formation processes, plant nutrition and improvement of phytosanitary condition of crops [2-6]. Modern microbial preparations allow to minimize the level of chemicals in soils of agrocenoses and, accordingly, the risk of pollution of plant products and the environment. Moreover, their use allows to reduce energy and economic costs associated with production and use of mineral fertilizers [2-6]. Consequently, the use of biological preparations is one of the techniques of increasing plant productivity while maintaining soil fertility without deterioration of the ecological state of environment.

An important place in the provision of population with valuable food belongs to melon growing $[7 ; 8]$. But now the production of gourds for adequate nutrition of the population does not meet justified scientific standards for several reasons, including the lack of perfect technologies of growing crops and others. It is emphasized that the implementation of the capacity of gourds is possible only under the condition of optimal plant nutrition, presence of nutrients in the soil and their availability [8]. At this, an important factor is the revitalization and intensification of certain biological processes in the basal layer of soil, which contributes to plant provision with physiologically active substances. The literature reports on the effectiveness of combined application of mineral fertilizers and bacterial fertilizers based on associative nitrogen fixers: Azorizin-8 (Azospirillum lipoferum) and Agrofil (Agrobacterium radiobacter) in watermelon growing technology on ordinary black soil with irrigation in the Lower Don conditions. Thus, local application of Azorizin-8 at sowing allowed to save mineral nitrogen up to $60 \mathrm{~kg} / \mathrm{ha}$, Agrofil $-45 \mathrm{~kg} / \mathrm{ha}$ [9]. The study of the effectiveness of biological preparations for watermelon on different agricultural backgrounds in dryland conditions in the area of industrial melon growing of Ukraine, as a part of its growing technology biologizing, was not conducted.

The goal of the research was to study the influence of microbial preparations for preplant bacterization of seeds at different agricultural backgrounds on watermelon yield, product quality and economic efficiency of agronomical practices.

Materials and methods. The study was conducted in 2012-2013 in dryland conditions in the stationary field experiment, laid in State enterprise Experiment Farm "Velyki Klyny" of Southern State Agricultural Experiment Station of the Institute of Water Problems and Land Reclamation of NAAS. Soil - solodized black soil of sabulous granulometric texture. Humus content in the topsoil - 1.0-1.2\%; $\mathrm{pH} 6.8-7.2$; gross forms content (\%): $\mathrm{N}-0.012-0.016$, 
$\mathrm{P}_{2} \mathrm{O}_{5}-0.038-0.045, \mathrm{~K}_{2} \mathrm{O}-0.55-0.67$ and movable forms $(\mathrm{mg} / 100 \mathrm{~g})$ : nitrates -0.35 0.76, phosphorus - 3.5-5.5, exchangeable potassium - 28.0-38.5.

Watermelon of Alliance variety was grown. Area of record plot $-100 \mathrm{~m}^{2}$, seedling plot $-120 \mathrm{~m}^{2}$. The area under the experiment - 0.77 ha. Repetition of the experiment quadruple. Number of record plants -40 . Planting system (plant nutrition area) $-1.4 \mathrm{~m}$ $\mathrm{x} \quad 0.8 \mathrm{~m}=1.12 \mathrm{~m}^{2}$ per plant. Two-factor experiment: factor $\mathrm{A}$ - bacterization (preplant treatment of seeds with microbial preparations) and factor B - agricultural backgrounds (without fertilizers; recommended dose of fertilizers $\mathrm{N}_{60} \mathrm{P}_{90} \mathrm{~K}_{60}$ applied in bulk (overall), $50 \%$ of the recommended dose of fertilizers $-\mathrm{N}_{30} \mathrm{P}_{45} \mathrm{~K}_{30}$ (applied locally in the row), $25 \%$ of the recommended dose of fertilizers $-\mathrm{N}_{15} \mathrm{P}_{23} \mathrm{~K}_{15}$ (applied locally in the row). Experiment scheme is represented in tables 1-6. Mineral fertilizers were applied according to the experiment scheme: overall or locally. The overall application (in bulk) was provided by the following unit: tractor MTZ-82 + lift-type fertilizer spreader HPY-0,5 (NRU-0.5), local (in the row) correspondingly tractor MTZ-82 + cultivator-fertilizer KPH-4,2 (KRN-4.2).

Microbial preparations (Biogran integrated microbial preparation including nitrogen-fixation bacteria Azotobacter and physiologically active substances of natural origin; Azotobakteryn - on the basis of bacteria of Azotobacter genus; Albobacteryn based on phosphate-mobilizing bacteria Achromobacter album 1122) are produced at the Institute of Agricultural Microbiology and Agroindustrial Manufacture, NAAS. Azotobakteryn and Albobakteryn were used for preplant bacterization at the rate of 40-50 $\mathrm{ml}$ of suspension per 1 hectare seed rate. Granulated microbial preparation Biogran was applied into soil locally in the row at sowing.

Farming culture is zonal, except investigated agronomical practices. Precursor - winter wheat. Record of harvest was carried out twice - during the onset of individual ripeness (flagellum desiccation at the fruit) and full ripeness of fruits. The study was performed using field and laboratory methods using the following methods and techniques: soil sampling - by DSTU 4287:2004, soil biological activity determination - by Shtatnovyi [10], nitrates content colorimetrically with phenoldisulfonic acid by Grandval-Lajoux (GOST 26951-86), movable phosphorus - by Machyhin (DSTU 41152002), exchangeable potassium - in $1 \%$ ammonium extract at flame photometer (DSTU 4115-2002), leaf surface area - by O. Ya. Kashcheiev [11], crop record - by a direct method with distribution of fruits by fractions [12], dry matter content in fruits by refractometric method [12], sugars - by Bertrand cyanide micromethod modified by Bierry (GOST 8756 13-87), ascorbic acid by Murray method (GOST 24556-89), nitrates - by potentiometric method (GOST 5048-89). Mathematical processing of the results was performed by dispersion method [13]. Experiments initiation, conducting observations and records during crop growing season were performed according to the methods of research in vegetable and melon growing [12] and methods of selection process and conducting field experiments with gourds [14].

Agrometeorological conditions in spring of 2012-2013 were unfavourable for obtaining shoots, growth and development of watermelon. The first half of 2012-2013 was characterized by unfavourable conditions for restocking of moisture in the soil. Thus, the spring rainfall was $42.1 \mathrm{~mm}$ (at the normal rate of $101 \mathrm{~mm}$ ). Spring rainfall was uneven, that did not allow to accumulate sufficient moisture in the soil before planting watermelon. Moreover, after dry April enough rainfall in May fell only in the third decade that's why during the study years mass shoots of watermelon were obtained in early June. Summer, along with higher temperature regime compared to long-time annual average was characterized by low rainfall. Thus, in summer 2012 total precipitation was $43.3 \mathrm{~mm}$ (at the normal rate of $132 \mathrm{~mm}$ ), and in 2013, respectively $66.9 \mathrm{~mm}$ and was almost twice lower than normal rate. Lack of rainfall and high temperatures led to insufficient moisture reserves in the soil. In the time of sowing of watermelon the stocks of productive moisture in $0-100 \mathrm{~cm}$ soil layer were $109.5-112.5 \mathrm{~mm}$. Beginning with the phase of flowering watermelon plants were under the conditions of soil moisture shortage. Under the conditions of prolonged drought (from early 
June to the end of growing season) growth and development of watermelon plants took place due to the above mentioned moisture in the soil.

Thus, the results of the study lead to the following conclusions.

1. In the conditions of dry Steppe on solodized black soil the highest effect of the use of integrated biological preparation Biogran was determined on the $50 \%$ background of the recommended dose of fertilizer.

2. The highest level of soil biological activity in watermelon rhizospheric soil was marked in the phase of flowering at the application of Biogran on the background of application of the recommended dose of fertilizer. The highest rates of watermelon leaf surface $\left(6917.5 \mathrm{~m}^{2} / \mathrm{ha}\right)$ were recorded using in the variant with Biogran use on the $50 \%$ background of the recommended dose of fertilizer.

3. The highest yield of watermelon of Alliance variety was obtained in the variant with the use of Azotobakteryn and Biogran at local application on the $50 \%$ background of the recommended dose of fertilizer.

4. The best economic performance was obtained in the variant with the use of Azotobakteryn for seeds bacterization at local application of $50 \%$ of the recommended dose of fertilizer. At this net profit amounted to $3829 \mathrm{UAH} / \mathrm{ha}$, the cost of 1 ton of product $259.1 \mathrm{UAH}$, the profitability level $-75 \%$ agricultural practices return - 105.7 UAH. At the application of Biogran the same profitability was received $(75 \%)$ and the lowest cost of production (257.2 UAH/t), but other indicators were slightly worse (net profit - 3799 UAH, agricultural practices return - 93.3 UAH).

5. In all variants of the experiment grown products meet quality category by quality indicators. The variant with the use of Azotobakteryn for seeds bacterization at local application on the $50 \%$ background of the recommended dose of fertilizer distinguished by high quality fruit parameters: dry matter content $-12.2 \%$, sugar $-9.38 \%$, ascorbic acid $-8.0 \mathrm{mg} \%$, at nitrate rate of $50.2 \mathrm{mg} / \mathrm{kg}$ (MAC - $60 \mathrm{mg} / \mathrm{kg}$ ). Along with this we should mentioned the variant with the use of Biogran at local application of $50 \%$ of the recommended dose of fertilizer in which grown products had slightly lower quality indicators (dry matter $-9.3 \%$, sugar $-6.5 \%$, ascorbic acid $-4.61 \mathrm{mg} \%$ ), but 2 times less nitrates $(24.7 \mathrm{mg} / \mathrm{kg})$ were observed in the fruits, which is an extremely valuable feature of product quality, since it allows virtually unlimited use of products for health care, dietary and baby food.

6. Products grown in the variant with the use of Albobakteryn on the $50 \%$ background of the recommended dose of fertilizer occupied intermediate value for its quality indicators (dry matter content $-9.3 \%$, sugar $-6.6 \%$, ascorbic acid $-5.05 \mathrm{mg} \%$, at nitrate contents $42.9 \mathrm{mg} / \mathrm{kg}$ ). 